\section{CONCEPTUAL MODEL OF MOBILE AUGMENTED REALITY FOR CULTURAL HERITAGE SITE TOWARDS ENJOYABLE INFORMAL LEARNING ASPECT}

Ulka Chandini Pendit*, Syamsul Bahrin Zaibon, Juliana Aida Abu Bakar

School of Multimedia Technology and Communication, Universiti Utara Malaysia, Kedah, Malaysia
Article history

Received

23 August 2015

Received in revised form

9 September 2015

Accepted

11 October 2015

*Corresponding author ulka.chandinipendit@gmail.com

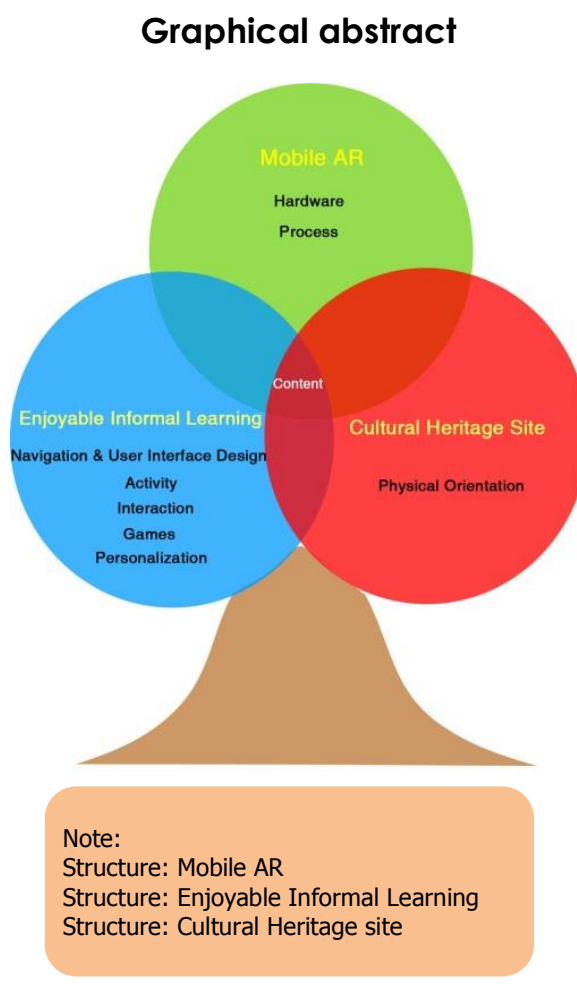

\begin{abstract}
Abstrak
Model konsep realiti luasan mudah alih (AR) untuk tapak warisan budaya berdasarkan menyeronokkan aspek pembelajaran tidak formal adalah dicadangkan untuk membantu pemaju teknikal atau kandungan untuk membangunkan aplikasi AR mudah alih khusus untuk tapak warisan budaya yang merangkumi aspek pembelajaran menyeronokkan. Model konseptual menyediakan kandungan, navigasi dan antara muka pengguna reka bentuk yang sesuai, interaktif, ciri-ciri, perkakasan, dan proses untuk menyediakan pembelajaran tidak formal dengan cara menyeronokkan di tapak warisan budaya menggunakan AR mudah alih. Model konseptual terdiri daripada tiga struktur, enam komponen, dan dua puluh sembilan elemen. Penggunaan model konseptual adalah fleksibel yang boleh dilaksanakan mengikut keperluan dan keutamaan pemaju.

Kata kunci: Model Konseptual, realiti Iuasan mudah alih, keseronokan pembelajaran tidak formal, tapak warisan budaya
\end{abstract}

(C) 2015 Penerbit UTM Press. All rights reserved

\subsection{INTRODUCTION}

Mobile augmented reality (AR) has been implemented at cultural heritage sites since fourteen years ago $[1,2,3,4,5,6,7]$. It has become an alternative for common traditional media (signs, interpretive board, and brochure) by visitor to refer for visiting information and guide. However, the existing mobile AR projects for visitor do not apply enjoyable informal learning aspect [8]. This is 
regrettable since visitor want to learn and gain meaningful experience from their visit, where informal learning is taken place.

Informal learning is a type of learning where visitor has the most control during process including objective and means of learning $[9,10]$. Visitor also expects to enjoy while visiting those interesting places. According to [11], they define enjoyable based on [12] works, where enjoyment appears in three necessary aspects: Engagement, Positive Affect, and Fulfilment. For people to enjoy an activity, they have to: (a) engage in the activity; (b) be positively affected in terms of satisfaction, excitement, contentment, or similar feelings; and (c) achieve fulfillment of needs or desires through the activity (although these needs may not be consciously realized a priori). Based on these aspects, this study promotes enjoyable informal learning to be embedded in mobile AR application for cultural heritage sites.

In order to promote this alternative, a conceptual model of mobile AR for cultural heritage site towards enjoyable informal learning (MARCHSTEIL) has been decided to be constructed $[8,13]$ by providing component of content, navigation and user interface design, interactivity, features, hardware, and process. The conceptual model explores the components that are appropriate for enjoyable informal learning at cultural heritage site by using mobile AR. The conceptual model was developed through extraction of enjoyable informal learning concept, comparative analysis, and literature reviews. The extraction of enjoyable informal learning concept was done to determine the components of the conceptual model. After the components were obtained, the comparative analysis was done to define the element of conceptual model. Afterwards, related literature had been reviewed to add other components of conceptual model. These components, elements and results of literature review were incorporated to form the proposed conceptual model. Then, the conceptual model was sent to a validation process. Validation consists of expert review and focus group discussion. However, in between these steps, field study and review of conceptual model were completed to respond to the feedback from expert review and focus group discussion. Then, all results from these activities were integrated to revise the conceptual model. However, this paper provides further deliberation about the conceptual model. It describes structure, component, and elements of conceptual model in detail. The conceptual model of MARCHSTEIL is provided at the end of the paper.

\subsection{CONCEPTUAL MODEL OF MOBILE AR FOR CULTURAL HERITAGE SITE TOWARDS ENJOYABLE (MARCHSTEIL) INFORMAL LEARNING}

The components were obtained from comparative analysis of mobile AR projects, mobile tourism guide, and mobile learning. The proposed conceptual model consists of two levels. The first level is divided into three structures and elements. Structure is the main topic of conceptual model which consists of Mobile AR, Enjoyable informal learning and Cultural heritage site (refer to Figure 1). Mobile AR includes Process and Hardware. Besides, Enjoyable informal learning comprises Navigation and User Interface Design, Activity, Games, Interaction, and Personalization. However, Cultural heritage site has one component only; Physical orientation. Furthermore, intersection of these three structures is called, Content. The element of Content is provided in detail in the second level, 3D model, 3D character, Text, Image, Sound, Audio, Animation, and Video. The next section explains the structure of conceptual model.

Structure of the conceptual model covers the main concepts, in which, mobile AR technology, enjoyable informal learning and cultural heritage site.

\subsection{Mobile AR}

Mobile AR technology consists of hardware and process needed for developing mobile AR for cultural heritage site towards enjoyable informal learning. The structure provides developer appropriate technological components in developing mobile AR application.

\section{Hardware}

Physical components needed for developing mobile AR for cultural heritage towards enjoyable informal learning. Hardware comprises handheld devices, such as, smart-phones and tablet.

\section{Process}

Steps or actions needed to develop mobile AR for cultural heritage site towards enjoyable informal learning. The followings are elements of process:

- Reconstruction. Reconstruct parts of wall of A'Famosa into 3D model by using 3DsMax.

- Registration. Align 3D object of wall of A'Famosa in the real world by tracking the position and orientation of user's view.

- Tracking. Track user's position and orientation by using sensor-based tracking, vision-based tracking, and hybrid-based tracking.

- Rendering. Generate 3D object of wall of A'Famosa and present it to the real environment of A'Famosa. 
- Interaction. Create interaction that occurs between system and user by shaking, blowing, rotating, leaning, and nodding the mobile phone and the head to retrieve information about A'Famosa.

\subsection{Cultural Heritage Site}

Cultural heritage site structure consists of components needed for developing mobile AR for enjoyable informal learning at cultural heritage site, such as, physical orientation. This component can be referred by developer to develop application which is taken place at cultural heritage site.

\section{Feature: Physical Orientation}

Physical orientation is included in component of feature. It is a set of functions to guide visitor while learning at cultural heritage site. Physical orientation comprises elements of show the surround interested places, show recommended route to the site, allow direction inquiry, show direction with virtual arrows overlay on real path, show map of the site and location of visitor within the site, show provided content, show visited route, and show the current position. For example: show other cultural heritage site near A'Famosa, show the route from airport to A'Famosa, enable the visitor to search location of A'Famosa, show direction to A'Famosa with virtual arrows overlay on real path from Saint Paul, show the map of A'Famosa and location of visitor within A'Famosa, show the provided content in A'Famosa, show the visited route at Melaka Heritage Site, and show the current position of visitor.

\subsection{Enjoyable Informal Learning}

Enjoyable informal learning includes components needed for learning in enjoyable way at cultural heritage site. It comprises activity, interaction, personalization and games. This structure provides developer to create application for informal learning in enjoyable way.

\section{Navigation and User Interface design}

Navigation and user interface design that is easy and helps visitor to learn in enjoyable way at cultural heritage site. Navigation and user interface design comprises element of provide thematic path, provide layered information, provide one-tap access for frequent menu, provide clue for scene with augmented content, provide shaped button, provide quick button to go to main menu, provide big size of font, provide appropriate size of content, and provide enough contrast between text and background. For example: provide theme of cultural heritage site based on colonialism era (Portuguese colonialism, Dutch colonialism, British colonialism), provide description about the structure and construction about A'Famosa and continued by history of formation of A'Famosa, provide "home" button for accessing the menu, provide clue in balloon to tell there is augmented scene in the area, provide play button in its shape in order to make visitor easy to access, provide 'home' button to the information menu to go to homepage quickly, provide three-fourth content size for the page, and provide white background for black text.

Interactivity: Activity

Activity is included in component of interactivity. It is a set of activities that can trigger the whole learning process at cultural heritage site by integrating the visitor, learning material, and learning environment. Activity includes take picture, edit/add information, create notes, save information and share information to social media. For example: provide option to take picture of A'Famosa, provide option to edit or add description of A'Famosa, provide option to create notes about experience of visiting A'Famosa, provide option to save the information of A'Famosa to personal device, and provide option to share information of A'Famosa to social media (Facebook and Twitter).

\section{Interactivity: Interaction}

Interaction is included in component of interactivity. It is a set of activities that enable visitor interacts naturally with the virtual object. Interaction includes shaking, blowing, rotating, leaning and nodding. For examples: enable visitor to shake their phone in order to retrieve the information about A'Famosa, enable visitor to blow the wall of A'Famosa to retrieve the information, enable visitor to rotate their phone to left or right in order to turn the 3D object to the preferred direction, enable visitor to lean or move the 3D object to left or right, and enable visitor to move the 3D object to up and down by nodding his/her head.

\section{Feature: Personalization}

Personalization is included in component of feature. It is a set of options that can be chosen by visitor in order to display the right content that suits visitor's desire. Personalization comprises historical period, interest, range of distance and language. For example: enable visitor to select the cultural heritage site in the range of 1819-1900 or 1901-present, enable visitor to choose the cultural heritage site to be visited based on personal interest, enable visitor to select the cultural heritage site within the range $(0-5 \mathrm{~km}, 6-$ $10 \mathrm{~km}$, and 11-15 km), and enable visitor to choose the language based on their preferences. 


\section{Feature: Games}

Games is included in component of feature. It is type of games that help visitor to refresh, stimulate and enjoy the learning process at cultural heritage site. It consists of adventure games (treasure hunt) and multiple choice quiz.

\subsection{Intersection between Mobile AR, Enjoyable Informal Learning, and Cultural Heritage Site}

Intersection between mobile AR technology, enjoyable informal learning and cultural heritage site is the content. A set of media representation equipped with criteria that can be referred as guideline to conduct enjoyable informal learning at cultural heritage site. Content comprise eight elements:

i) 3D Model. 3D model has one criterion, which is, overlay certain part that is lost. The lost part of cultural heritage is reconstructed into 3D model. For example: the wall of A'Famosa has been lost so it can be reconstructed into 3D model.

ii) 3D Character. 3D character has two criteria, which are, represent noble people in the past and act as virtual guide. The noble people are made into 3D character. Also, these 3D characters can be the guide for the visit. For example, Alfonso d'Alburqueque, Captain of Portuguese, as 3D character who becomes guide for A'Famosa Cultural Heritage Site.

iii) Text. Text has one criterion: provide description in point by point. All descriptions about cultural heritage site are presented in point by point. Description contains information about cultural heritage site, such as, history and background information of site.

iv) Image. Image has two criteria: overlay certain part that is lost and provide old picture about the site, noble people, and events. The lost or broken part of cultural heritage site can be replaced by image. In addition, image also can provide the picture how the site looked like, picture of important people of the site, and picture of important events occurred the site.

v) Audio. Audio has three criteria: provide recorded audio presented by narrator who has the same age with visitor, provide in-depth information in storyline and provide audio with maximum duration in five minutes. Audio should present information about history of cultural heritage site in deep and detail. The information is conveyed through storyline and narrated by narrator who has the same age with visitor. Moreover, it should be not more than five minutes. For example: story that tells how A'Famosa was built by Portuguese.

vi) Sound. Sound has one criterion, which is, provide ambience of the site in the past. This is ambience of site that does not exist anymore that can help visitor imagine how the site was. For instance, sound of bomb during the war, conversation between inhabitants, and sound of captain's car.

vii) Animation. Animation has three criteria, which are, provide in-depth and special information in storyline, use noble people as character, and provide animation with maximum duration in ten minutes. Animation should present history about cultural heritage site that is deep and special which is not presented at cultural heritage site. It is conveyed through storyline and played by the noble people. The duration is should be not more than ten minutes. For example: story about how the war between Portuguese and Dutch long time ago happened in A'Famosa.

viii) Video. Video has three criteria: provide in-depth and special information in storyline, use noble people as character, and provide video with maximum duration in ten minutes. The information should be about history of cultural heritage site that is deep and special which is not provided at cultural heritage site. It is presented in storyline and played by noble people. The duration is should be not more than ten minutes. For example: story about how the war between Portuguese and Dutch long time ago happened in A'Famosa.

Content is divided into two types, push content and pull content. Push content is type of content that appears automatically when visitor reaches certain area and pull content is type of content that should be retrieved by visitor. Elements with (\#) symbol can be used as single element or combined with other elements. The proposed conceptual model is displayed in Figure 1 and Figure 2. 


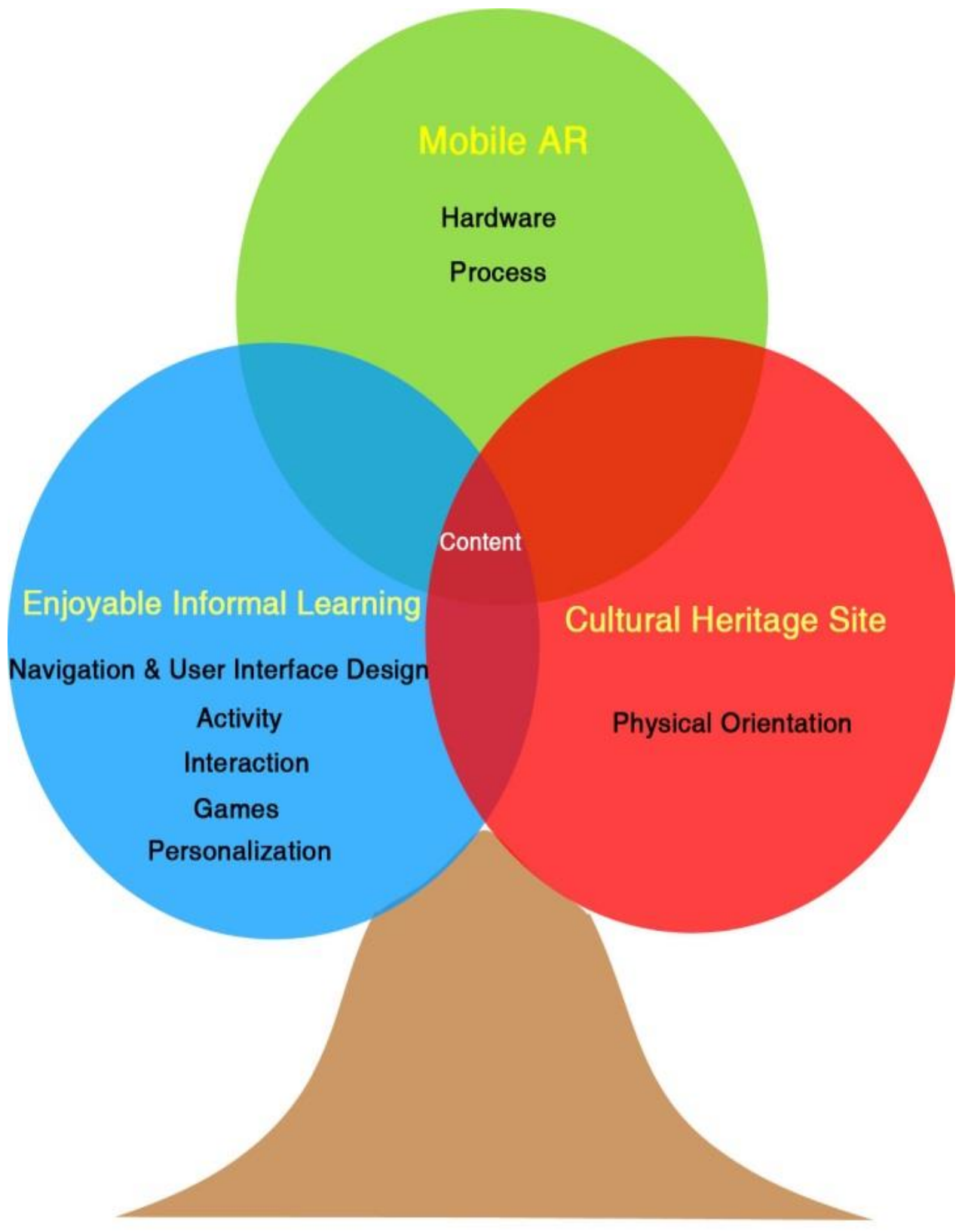

Note:

Structure: Mobile AR

Structure: Enjoyable Informal Learning

Structure: Cultural Heritage site

Figure 1 Proposed Conceptual Model of MARCHSTEIL (First Level) 


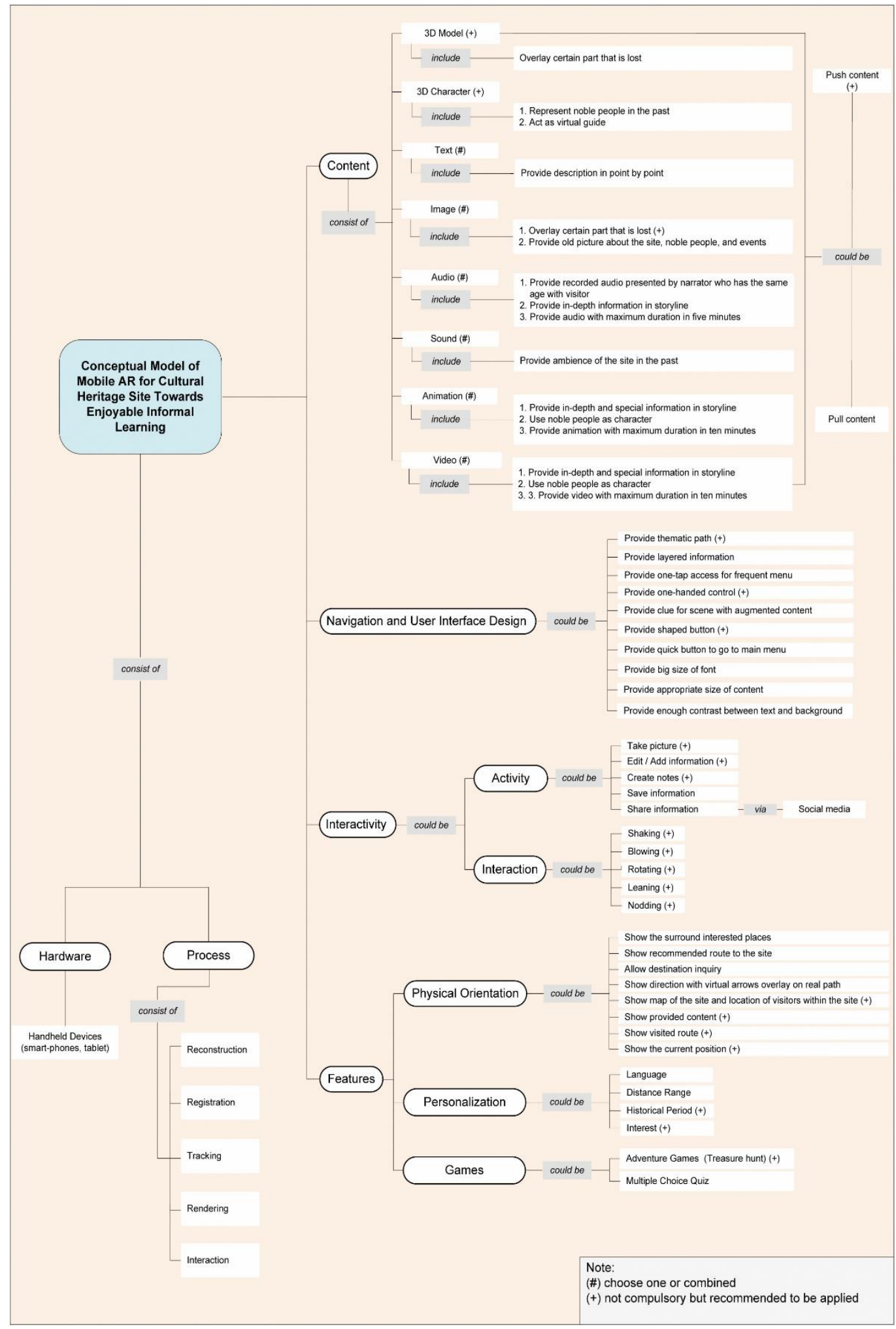

Figure 2 Proposed Conceptual Model of MARCHSTEIL (Second Level) 


\subsection{CONCLUSION}

The conceptual model of MARCHSTEIL provides components for helping provision of enjoyable informal learning at cultural heritage site. It comprises content, navigation and user interface design, interactivity, features, hardware, and process for conducting enjoyable informal learning at cultural heritage site. The totals of components are six components with the support of twenty nine elements and three structures. They can be implemented flexibly, either by implementing the components based on domain (mobile AR, enjoyable informal learning, and cultural heritage site) or implementing the components to the whole domain of mobile AR for cultural heritage towards enjoyable informal learning. In a nutshell, the presence of conceptual model is hoped acts as guideline to help developer for creating mobile AR for enjoyable informal learning at cultural heritage site.

\section{Acknowledgement}

We acknowledge Ministry of Education Malaysia for Exploratory Research Grant Scheme and Universiti Utara Malaysia for the postgraduate research grant to Author 1.

\section{References}

[1] Anastasia Angelopoulou, Daphne Economou, Vassiliki Bouki, Li Jin, Chris Pritchard, and Frantzeska Kolyda. 2012. Mobile Augmented Reality for Cultural Heritage. In Nalini Venkatasubramanian, Vladimir Getov, and Stephan Steglich (Eds.). Mobile Wireless Middleware,
Operating Systems and Applications. Springer Berlin Heidelberg.

[2] Armanno, G., A. Bottino, and A. Martina. 2012. SkyLineDroid: An Outdoor Mobile Augmented Reality Application for Virtual Heritage. International Conference on Cultural Heritage and Tourism. 91-96.

[3] iTACITUS. [Online]. From: itacitus.org. [Accessed on $7^{\text {th }}$ June 2012].

[4] Kim J. and C. Park. Development of Mobile AR Tour Application for the National Palace Museum of Korea. 2011 International Conference on Virtual and Mixed Reality: New Trends-Volume Part 1. Orlando, FL, USA: Springer Berlin Heidelberg. 55-60.

[5] Byung-kuk Seo, Kangsoo Kim, and J-II Park. 2011. Augmented Reality-Based On-Site Tour Guide: A Study in Gyeongbokgung. In Reinhard Koch and Fay Huang (Eds.). Computer Vision-ACCV 2010 Workshops. Springer Berlin Heidelberg.

[6] Techcooltour. [Online]. From: techcooltour.com. [Accessed on 22nd May 2013].

[7] Vlahakis, V., J. Karigiannis, M. Tsotros, M. Gounaris, L. Almeida, D. Stricker, T. Gleve, I. T. Christou, R. Carlucci, and N. loannidis. 2001. ARCHEOGUIDE : First results of an Augmented Reality, Mobile Computing System in Cultural Heritage Sites. Conference on Virtual Reality, Archaeology and Virtual Heritage (VAST). 131-140.

[8] Pendit, U. C. and S. B. Zaibon. 2014. Enjoyable Informal Learning in Cultural Heritage Site using Mobile Augmented Reality: A Conceptual Model. Journal of Advances in Science and Technology. 2(3): 93-106.

[9] Mocker, D. W. and G. E. Spear. 1982. Lifelong Learning: Formal, Nonformal, Informal, and SelfDirected. Columbus.

[10] Lowry, C. M. 1989. Supporting and Facilitating SelfDirected Learning. ERIC Digest. 93: 1-4.

[11] Lin, A. C. H., W. D. Fernandez, and S. Gregor. 2012. Understanding Web Enjoyment Experiences and Informal Learning: A Study in A Museum Context. Decision Support Systems. 53(4): 846-858.

[12] Warner, R. 1980. Enjoyment. The Philosophical Review. $89(4): 507-526$.

[13] Pendit, U. C., S. B. Zaibon, and J. A. A. Bakar. 2014. Mobile AR for Cultural Heritage Site towards Enjoyable Informal Learning: A Revised Conceptual Model. Information Management \& Business Review. 6(5): 239-248. 